Original Research Paper

\title{
Pelatihan Pengolahan Kerupuk Ikan di Desa Ekas Buana Kecamatan Jerowaru Kabupaten Lombok Timur
}

\author{
Mursal Ghazali ${ }^{1 *}$, Risqa Rabbani ${ }^{2}$, Maya Sari $^{2}$, Muh.Hidayatur Rohman $^{2}$, M. Hamam Nasiruddin ${ }^{3}, \operatorname{Suherman}^{4}$, \\ Nurhayati ${ }^{5}$ \\ ${ }^{1}$ Program Studi Biologi, Fakultas MIPA, Universitas Mataram, Mataram, Indonesia \\ ${ }_{2}^{2}$ Program Studi Pendidikan Pancasila dan Kewarganegaraan, FKIP, Universitas Mataram, Mataram, Indonesia \\ ${ }^{3}$ Program Studi Agroekoteknologi, Fakultas Pertanian, Universitas Mataram, Mataram, Indonesia \\ ${ }^{4}$ Program Studi Peternakan, Fakultas Peternakan, Universitas Mataram, Mataram, Indonesia \\ ${ }^{5}$ Program Studi Teknologi Hasil Pertanian, Fakultas Pertanian, Universitas Muhammadiyah Mataram, Mataram, Indonesia
}

DOI: https://doi.org/10.29303/jpmpi.v4i2.683

Sitasi: Ghazali, M., Rabbani, R., Sari, M., Rohman, M. H., Nasiruddin, M. H., Suherman., \& Nurhayati. (2021). Pelatihan Pengolahan Kerupuk Ikan di Desa Ekas Buana Kecamatan Jerowaru Kabupaten Lombok Timur. Jurnal Pengabdian Magister Pendidikan IPA, 4(2)

Article history

Received: 03 Februari 2021

Revised: 08 Maret 2021

Accepted: 10 April 2021

*Corresponding Author:

Mursal Ghazali, Program Studi Biologi, Fakultas MIPA, Universitas Mataram, Mataram, Indonesia;

Email:

mursalghazali@unram.ac.id
Abstract: Ekas Buana adalah salah satu desa yang berada dibagian selatan Kabupaten Lombok Timur. Secara umum, mata pencaharian masyarakat ialah sebagai nelayan (nelayan tangkap dan budidaya) dan sebagian yang lain sebagai petani lahan kering. Kehidupan masyarakat di Desa Ekas Buana sama seperti kehidupan masyarakat yang ada di daerah pesisir lainnya, dimana penghasilan masyarakat cenderung tidak menentu. Oleh sebab itu, perlu dilakukan upaya pendampingan untuk memberikan alternatif lain sebagai sumber penghasilan tambahan. Salah satu usaha yang sangat cocok dengan daerah pesisir ialah pengolahan ikan. Pada kegiatan pengabdian ini dilakukan pelatihan pembuatan kerupuk dengan tambahan ikan tongkol (kerupuk ikan tongkol). Pengabdian ini bertujuan memberikan pengetahuan tambahan secara teoritis dan praktik mengenai proses pembuatan kerupuk ikan. Dari kegiaatan yang dilakukan dapat dilihat bahwa masyarakat yang mengikuti kegiatan pengabdian ini memiliki ketertarikan yang sangat tinggi. selain itu, pada saat pelaksanaan pendampingan atau praktik, masyarakkat terlibat langsung mengerjakan setiap tahapan. Meskipun demikian, belum ada yang siap untuk menjadikan kerupuk ikan sebagai usaha sampingan untuk meningkatkan pendapatan.

Keywords: Pendampingan; Kerupuk; Ikan Tongkol.

\section{Pendahuluan}

Ekas Buana adalah salah satu desa yang berada dibagian selatan Kabupaten Lombok Timur. Secara umum, mata pencaharian masyarakat ialah sebagai nelayan (nelayan tangkap dan budidaya) dan sebagian yang lain sebagai petani lahan kering. Sebagai desa yang berada di wilayah pesisir, sumber pendapatan masyarakat cenderung tidak menentu. Permasalahan ini merupakan permasalahan yang umum terjadi pada kehidupan masyarakat pesisir (Luciana et al., 2017; Pangerapan et al., 2018). Kondisi ini semakin diperparah oleh keterlibatan perempuan masih sangat terbatas. Oleh sebab itu, diperlukan upaya pembinaan masyarakat sebagai upaya peningkatan ekonomi. Salah satu peluang usaha yang potensial untuk dibina ialah usaha kerupuk ikan. 
Kerupuk ikan merupakan makan kering yang dibuat dari tepung atau nasi dengan penambahan daging ikan dan bahan lain yang diizinkan (BSN 1999). Masyarakat Indonesia mengonsumsi kerupuk sebagai camilan atau sebagai menu pelengkap makan utama, misalnya sebagai lauk. Kusuma et al. (2013) menyatakan bahwa tepung tapioka merupakan bahan baku utama yang digunakan sebagai bahan pembuatan kerupuk. Meskipun demikian, masyarakat Indonesia sudah terbiasa menggunakan bahan lain seperti nasi atau sagu. Selain itu, penambahan bahan lain sebagai umum dilakukan untuk meningkatkan nilai gizi dari kerupuk. Salah satunya adalah penambahan daging ikan yang berfungsi sebagai penambah cita rasa dan aroma. Selain itu, penambahan daging ikan berfungsi menambah kandungan protein pada kerupuk. Persentase daging ikan yang ditambahkan tidak lebih dari 30\% (Natalia et al., 2019; Zulisyanto et al, 2016). Beberapa jenis ikan yang umum digunakan ialah ikan nila (Purnamayati et al., 2019), ikan tengiri (Lilimantik \& Sofia, 2015), ikan tuna ( Deni et al., 2013), atau jenis ikan lain seperti ikan tongkol.

Ikan tongkol adalah salah satu ikan laut yang memiliki daging tebal dengan kandungan protein tinggi. Selain mengandung protein, ikan tongkol juga mengandung omega 3 , vitamin dan mineral yang dibutuhkan oleh tubuh manusia (Hafiludin, 2011). Selain itu, ikan tongkol memiliki rasa yang lezat.

Inovasi lain yang diberikan pada pelatihan pembuatan kerupuk ikan tongkol saat ini ialah penggunaan daun pisang untuk membungkus adonan kerupuk sehingga tercipta aroma yang khas dari kerupuk ikan tersebut. Dengan demikian pelatihan "Pengolahan Kerupuk Ikan yang diberikan kepada Mitra yang ada di Desa Ekas Buana" diharapkan mampu diterapkan dan dijadikan sebagai usaha dalam upaya meningkatkan ekonomi masyarakat.

\section{Metode Pelaksanaan}

Kegiatan pengabdian pada masyarakat dilaksanakan dalam 3 sesi, 1) Survei pengetahun Mitra, 2) penyampaian teori pembuatan kerupuk dan 3) praktik langsung cara pembuatan kerupuk ikan tongkol.

\section{a. Survei tingkat pengetahuan mitra}

Pengetahuan mitra tentang kerupuk ikan berbeda beda. Oleh sebab itu, dilakukan survei untuk mengetahui pemahaman mitra. Untuk mengetahui perubahan pemahaman mitra, maka survei dilakukan sebanyak dua kali yaitu sebelum dan setelah kegiatan pelatihan dilakukan. Secara umum poin perntanyaan saat survei terdiri dari identitas diri, pengetahuan tentang kerupuk, pembuatan kerupuk, modifikasi kerupuk, penggunaan bahan ramah lingkungan, pengemasan serta peluang pemasaran.

\section{b. Penyampaian teori}

Sesi penyampaian teori merupakan sesi pemaparan teoritis prinsip pembuatan kerupuk ikan. Pada sesi ini dijelaskan proses pembuatan kerupuk ikan mulai dari penyiapan bahan, pengolahan sampai pengemasan. Kegiatan penyampaian teori juga diisi dengan kegiatan diskusi terkait proses pembuatan kerupuk ikan dan potensi modifikasi dengan penambahan bahan lainnya.

\section{c. Proses pembuatan kerupuk ikan}

Pembuatan kerupuk ikan tonggkol mengacu pada (Natalia et al., 2019) yang telah dimodifikasi. Secara rinci, langkah-langkah pembuatan kerupuk ikan tongkol sampai pengemasan adalah sebagai berikut:

\section{- Pembersihan Ikan}

Pencucian atau pembersihan ikan berfungsi untuk mengeluarkan insang, isi perut serta kotoran yang menempel. Kemudian filet ikan dengan memisahkan kulit ikan dengan dagingnya. Setelah itu cuci ikan dengan air mengalir sampai bersih.

\section{- Penggilingan Ikan dan Bumbu}

Ikan yang telah dibersihkan kemudian digiling menggunakan blender (chopper) sampai ikan menjadi halus. Proses selanjutnya yaitu penggilingan bumbu yang digunakan sebagai tambahan olahan kerupuk ikan yaitu bawang putih, garam, gula, dan ketumbar. Bumbu digiling sampai halus.

- Menimbang bahan

Langkah selanjutnya yang dilakukan adalah menimbang bahan-bahan yang digunakan untuk membuat kerupuk ikan. Adapun bahanbahan yang ditimbang yaitu ikan tongkol yang telah dihaluskan sebanyak 200 gr, kemudian timbang tepung tapioka sebanyak 300 gr.

- Pembuatan adonan kerupuk

Pembuatan adonan dilakukan dengan mengikuti lengkah berikut: siapkan baskom, kemudian masukan 2 butir telur ke dalam baskom. 
Kocok telur sampai berbusa selanjutnya tambahkan 200 gr ikan tongkol, 1/2 sdt soda kue dan bumbu yang telah dihaluskan, selanjutnya aduk secara merata agar bahan-bahan dapat menyatu. Setelah bahan-bahan tercampur merata kemudian ditambahkan 300 gr tepung tapioka. Kemudian aduk menggunakan tangan hingga menjadi adonan yang padat.

- Pembungkusan adonan kerupuk

Adonan yang telah jadi kemudian dibentuk seperti tabung atau seperti lontong. Adonan yang yang telah dibantuk kemudia dibungkus dengan daun pisang yang telah diolesi minyak goreng.

- Pengukusan

Sebelum adonan dikukus di dalam panci kukusan, langkah pertama panaskan air dalam panci kukusan sampai mendidih. Setelah air mendidih masukan bungkusan adonan kerupuk kedalam panci kukusan. Kemudian kukus adonan kerupuk antara 2 sampai 4 jam sampai matang, dinginkan adonan selama lebih kurang 15 menit.

- Pemotongan dan Penjemuran

Hasil pengukusan yang telah didinginkan kemudian dipotong tipis dan rata, kemudian dijemur. Penjemuran kerupuk dilakukan antara 1 sampai dengan 3 hari. Lama waktu penjemuran tergantung pada ketebalan kerupuk dan cuaca.

- Penggorengan dan Pengemasan

Penggorengan kerupuk dilakukan dengan menggunakan minyak yang cukup banyak atau dengan kata lain, ketika dilakukan penggorengan kerupuk harus tenggelam untuk memaksimalkan pematangan. Kemudian kerupuk digoreng hingga berwarna kuning keemasan. Kerupuk yang telah digoreng kemudian ditiriskan dan dibiarkan dingin. Selanjutnya kerupuk siap dikemas dan diberi label.

\section{Hasil dan Pembahasan}

\section{Penyampaian Teori}

Perguruan tinggi adalah pusat pengetahuan yang memiliki kemampuan dalam menyelesaikan permasalahan yang terdapat dimasyarakat. Salah satu peranan perguruan tinggi ialah transfer ilmu pengetahuan yang dapat dilakukan pada berbagai bidang. Transfer ilmu pengetahuan dapat dilakukan melalui penyampaian teoritis atau penyuluhan yang bertujuan untuk memperkaya pengetahuan masyarakat (Ghazali et al., 2018). Pada kegiatan pengabdian ini, teori yang disampaikan terkait dengan pengolahan ikan tongkol sebagai bahan tambahan pada proses pembuatan kerupuk. Masyarakat yang hadir menjadi peserta menunjukkan antusias yang cukup tinggi.

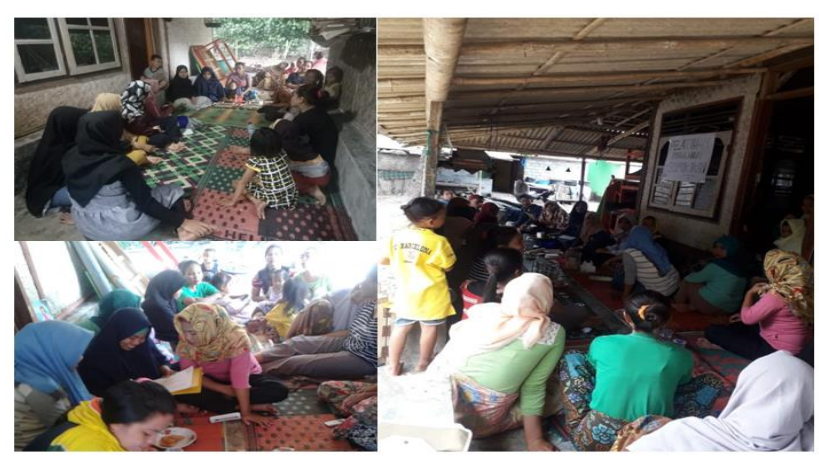

Gambar 1. Kegiatan penyampaian teori terkait pelatihan pembuatan kerupuk ikan tongkol di Dusun Ekas Buana, Kecamatan Jerowaru, Lombok Timur.

Antusiame masyarakat yang hadir dapat dilihat dari munculnya berbagai pertanyaan terkait pembuatan kerupuk ikan. Dua pertanyaan yang paling banyak ingin diketahui oleh peserta ialah:

P1: Ini bisa pakai ikan lain dalam pembuatannya?

Jawaban: pembuatan kerupuk ikan tidak harus mennggunakan ikan tongkol, bias juga menggunakan ikan jenis lainnya. Misalnya ikan teri, sarden atau ikan lain yang melimpah pada musim tertentu. Tetapi penggunaan ikan harus memperhatikan nilai ekonomisnya. Sangat disarankan untuk menggunakan ikan yang mudah didapatan dan yang memiliki harga yang relative murah. Sehingga kerupuk yang dihasilkan apabila untuk tujuan bisnis menjadi lebih terjangkau. Penggunaan ikan tongkol pada pelatihan ini disebabkan karena ikan tongkol memiliki harga yang murah dan daging lebih tebal.

(5) P2: Apakah Ikannya boleh digiling secara tradisional, karena tidak semua kami memiliki blender?

Jawaban: Boleh ibu-ibu, karena prinsip penggunaan blender ialah untuk menghaluskan daging ikan, jadi tidak harus menggunakan blender. Ibu-ibu dapat menggunakan pengiling secara tradisional yang penting dagingnya menjadi halus dah mudah untuk dicampurkan ddengan bahan-bahan yang lain. 
Harapan terbesar dari penyampaian teori ini adalah sebagai gambaran awal bagi peserta pelatihan tentang apa yang akan dikerjakan selama mengikuti pelatihan. Selain itu, prinsip tiap proses juga disampaikan sehingga peserta dapat melalukan modifikasi sesuai dengan alat dan bahan yang dimiliki.

\section{Pendampingan Pembuatan Kerupuk Ikan}

Selain transfer pengetahuan dengan metode penyuluhan atau penyampaian teori, transfer ilmu pengetahuan tentang pengolahan ikan tongkol menjadi kerupuk ikan juga dilakukan dengan pendampingan atau praktik langsung membuat kerupuk. Kegiatan ini bertujuan untuk meningkatkan pengetahuan peserta melalui keterlibatan langsung dalam proses pembuatan krupuk ikan tongkol. Sehingga diharapkan setelah kegiatan ini selesai, masyarakat dapat secara mandiri untuk melanjutkannya sebagai kegiatan usaha yang dapat memberikan penghasilan tambahan.

Kegiatan pembuatan kerupuk ikan tongkol diawali dengan pembersihan ikan tongkol untuk mendapatkan daging ikan yang bersih. Langkah berikutnya ialah memisahkan ikan dari tulangnya sehingga daging ikan yang didapatkan bersih dari tulang. Langkah yang tidak kalah pentingnya ialah pembuatan bumbu.

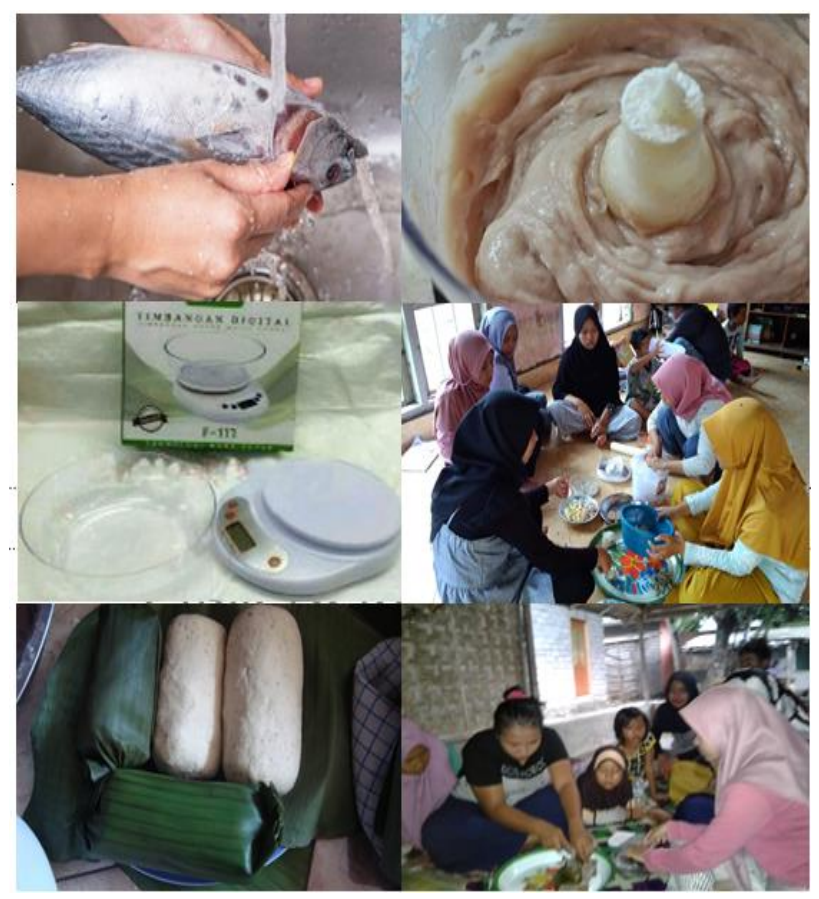

Gambar 2. Proses pembuatan kerupuk ikan tongkol.
Himatullah et al., (2017) menyatakan bahwa salah satu faktor yang menentukan cita rasa dalam pembuatan berbagai olahan makanan adalah bumbu, termasuk pembuatan kerupuk ikan. Bumbu pada kerupuk ikan dapat disesuaikan dengan selera masing-masing bila untuk konsumsi. Tetapi untuk produk yang akan diperjual-belikan cita rasa produk disesuaikan dengan segmen pasar yang akan dituju. Pada kegiatan pengabdian ini, rasa kerupuk yang diproduksi ialah rasa original. Artinya bahwa rasa kerupuk yang dihasilkan hanya terjadi perbedaan akibat penambahan daging ikan tongkol saja.

Faktor lain yang tidak kalah pentingnya dengan cita rasa ialah adonan bahan kerupuk. Adonan yang dihasilkan tidak boleh terlalu keras maupun terlalu lembek. Adonan yang terlalu keras akan membuat waktu pengukusan menjadi lebih lama, sementara adonan yang terlalu lembek akan menyebabkan adonan yang telah dikukus lebih susah untuk dipotong. Oleh sebab itu, kualitas adonan menjadi perhatian sebagai upaya menjaga kualitas produk terutama dari sisi tampilan.

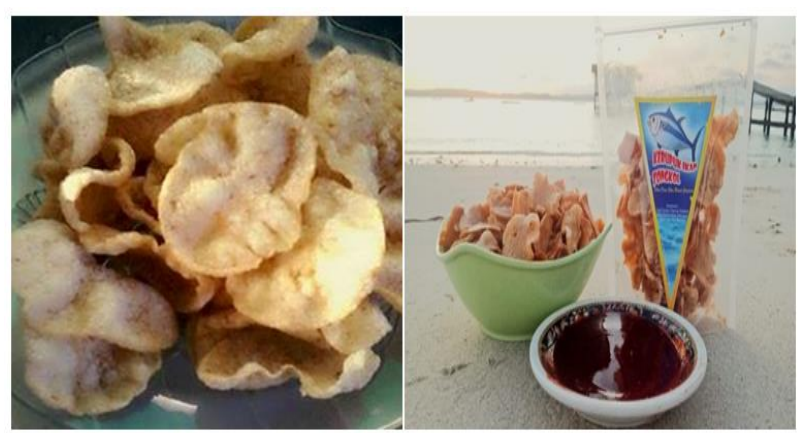

Gambar 3. Hasil pengolahan kerupuk ikan tongkol, kerupuk ikan tongkol yang telah digoreng(kiri) dan kerupuk yang telah dikemas dalam plastik klip (kanan).

Produk krupuk ikan yang diperdagangkan harus memiliki tampilan yang menarik. Beberapa tampilan yang menjadi perhatian antara lain ialah warna, bentuk kerupuk yang dipasarkan serta kemasan. Untuk mendapatkan warna kerupuk ikan yang menarik, harus memperhartikan lama dan suhu saat menggoreng (Tumbel \& Manurung, 2017). Penggorengan yang terlalu lama akan menyebabkan warna kerupuk menjadi coklat terlebih lagi apabila digoreng pada suhu minyak yang terlalu tinggi. Selain tampilan kerupuk. Untuk meningkatkan minat pembeli, maka kemasan kerupuk harus dibuat menarik. 


\section{Perubahan Persepsi Mitra}

Secara umum warga yang menjadi mitra memiliki pengetahuan yang cukup luas tentang kerupuk, terutama kerupuk yang berbahan nasi. Hal ini disebabkan mitra sering memanfaatkan nasi lebih pada acara syukuran untuk membuat kerupuk. Meskipun demikian, modifikasi dengan menambahkan bahan tertentu pada kerupuk belum banyak yang faham. Pengetahuan mitra tentang pemanfaatan ikan tongkol sebagai bahan tambahan pada pebuatan kerupuk beranekaragam. Sebagian mitra hanya memahami bahwa jenis ikan yang ditambahkan hanya ikan Tengiri dan udangudangan. Sementara sebanyak $20 \%$ mitra belum tahu tentang penggunaan tongkol sebagai bahan tambahan pada pembuatan kerupuk. Padahal, pada musim tertentu, sering terjadi panen melimpah untuk jenis ikan tertentu, termasuk tongkol dan dijual dengan harga sangat murah. Setelah adanya pelatihan baru sebagian mitra mengetahui atau memahami bahwa penambahan daging ikan dapat dilakukan dan menghasilkan cita rasa kerupuk yang lezat dan bergizi.

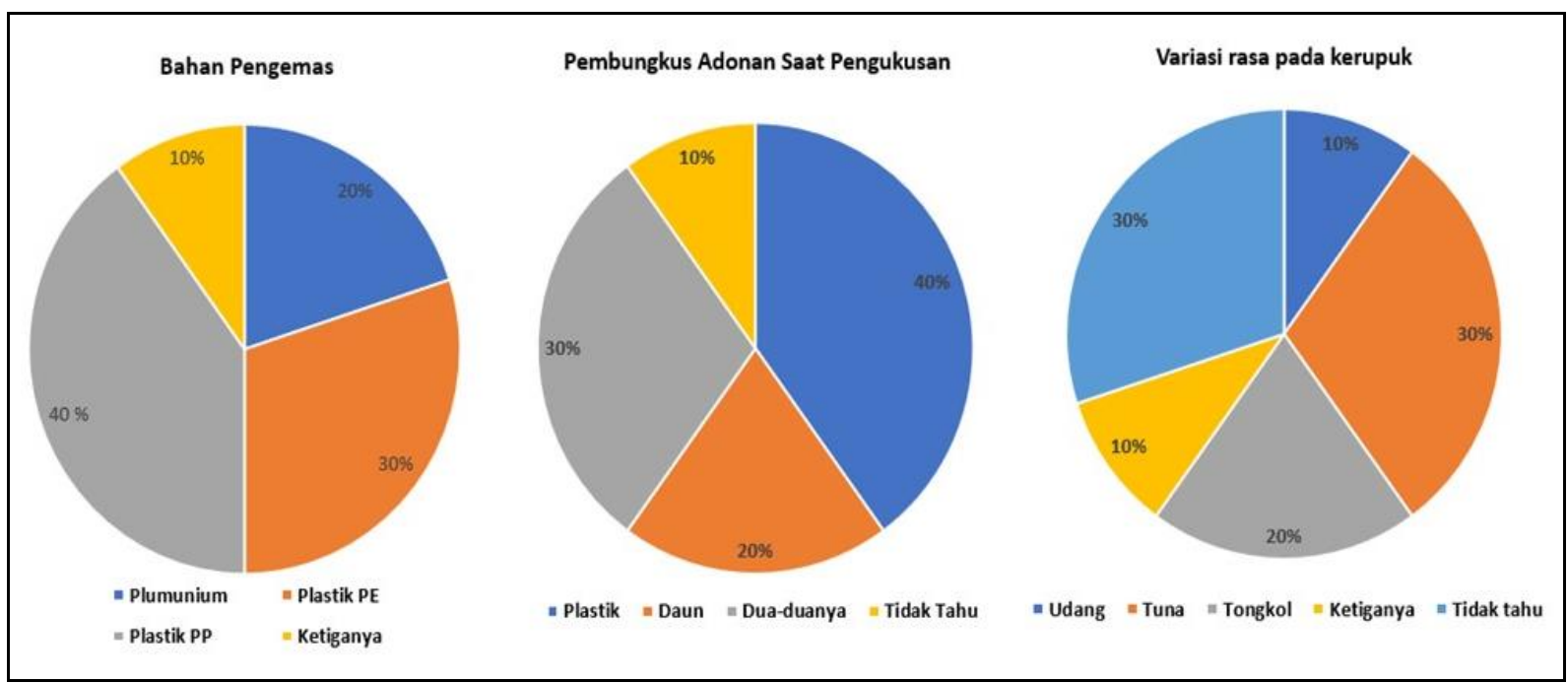

Gambar 4. Persepsi mitra sebelum pelaksanaan kegiatan pengabdian terhadap penggunaan bahan untuk kemasan produk, pembungkus adonan saat pengukusan dan penambahan bahan lain untuk memperbanyak varian rasa pada kerupuk.

Selain itu, pada kegiatan pengabdian ini juga digunakan bahan alami berupa daun pisang untuk membungkus adonan pada saat pengukusan. Pada dasarnya mitra mengetahui bahwa penggunaan daun pisang sudah umum dilakukan. Tetapi sebanyak $10 \%$ tidak mengetahui bahwa daun pisang dapat digunakan sebagau pembungkus adonan saat pengukusan (Gambar 4.). Hal ini disebabkan karena mitra hanya pernah membuat kerupuk dari nasi sisa yang tidak membutuhkan pembungkus (Nasi langsung dikukus). Selain itu, kebanyakan menggunakan pembungkus berbahan plastik. Beberapa alasan yang diungkapkan ialah ketersediaan yang banyak (beli diwarung), harga murah dan lebih praktis (hanya dimasukkan tanpa ada perlakuan). Sementara itu, penggunaan daun pisang relative lebih susah karena harus melalui beberapa proses sehingga dapat digunakan. Persepsi dan pemahaman masyarakat harus dirubah, walaupun sedikit sulit. Beberapa hal yang dilakukan untuk merubah persepsi dan pemahaman ini, salah satunya adalah Menjelaskan tentang dampak jangka panjang penggunaan plastik terutama yang digunakan dengan pemanasan.

\section{Kesimpulan}

Berdasarkan hasil pelaksanaan pengabdian yang dilakukan dapat disimpulkan hal-hal berikut:

1. Masyarakat memahami teori tentang dasar-dasar pembuatan kerupuk ikan, ditandai dengan munculnya ide kreatif untuk memodifikasi alat dan bahan yang digunakan.

2. Masyarakat memahami proses pembuatan kerupuk ikan, dilihat dari trampil dan cekatan peserta pelatihan saat kegiatan berlangsung.

3. Pemahaman masyarakat tentang penambahan bahan lain seperti ikan tongkol pada kerupuk, penggunaan daun pisang untuk membungkus adonan saat pegukusan dan penggunaan 
berbagai jenis plastik untuk pengemasan mengalami peningkatan.

\section{Saran}

Kegiatan pendampingan pada masyarakat sebaiknya dilakukan secara terus menerus terutama individua tau kelompok yang memiliki minat tinggi untuk mengembangkan usaha tersebut. Selain itu, perlu dilakukan kerjasama dengan Pemerintah Desa sehingga inisiasi usaha tersebut dapat dijadikan prioritas pengembangan usaha khas Desa Ekas Buana.

\section{Ucapan Terima Kasih}

Ucapan terima kasih di sampaikan kepada LPPM Universitas Mataram, Kepala Desa Ekas Buana, Kepala Wilayah Dusun Ekas, Mitra serta semua pihak yang telah memberikan dukungan sehingga pelaksanaan pelatihan pembuatan kerupuk ikan dapat berjalan lancar.

\section{Daftar Pustaka}

Badan Standardisasi Nasional. 2009. Standard Nasional Indonesia. 01-2713-2009. Kerupuk Ikan. Badan Standardisasi Nasional, Jakarta.

Deni, S., Hardjito, L., \& Salamah, E. (2013). Pemanfaatan Daging Ikan Tuna Sebagai Kerupuk Kamplang dan Karakterisasi Produk Yang Dihasilkan. Jurnal Ilmiah agribisnis dan Perikanan, 6(2), 6-14.

Ghazali, M., Aryanti, E., Kurnianingsih, R., \& Sunarpi, H. (2018). Pemanfaatan Ekstrak Rumput Laut Sebagai Pupuk Organik Pada Pertanian Lahan Sempit Di Desa Lepak Lombok Timur. Jurnal Pengabdian Magister Pendidikan IPA, 1(1), 95-100.

Hafiludin, H. (2011). Karakteristik Proksimat Dan Kandungan Senyawa Kimia Daging Putih Dan Daging Merah Ikan Tongkol (Euthynnus affinis). Jurnal Kelautan, 4(1), $1-10$.

Hikmatulloh, E., Lasmanawati, E., \& Setiawati, T. (2017). Manfaat Pengetahuan Bumbu Dan Rempah Pada Pengolahan Makanan Indonesia Siswa Smkn 9 Bandung. Jurnal Media Pendidikan, Gizi dan Kuliner, 6(1), 9.

Kusuma, T. D., Suseno, T. I. P., \& Surjoseputro, S. (2013). Pengaruh Proporsi Tapioka Dan
Terigu Terhadap Sifat Fisikokimia Dan Organoleptik Kerupuk Berseledri. Jurnal Teknologi Pangan dan Gizi, 12(1), 17-28.

Lilimantik, E., \& Sofia, L. A. (2015). Pengolahan Kerupuk Ikan Tenggiri (Laporan Pengabdian No. 664.02). Banjarbaru: Universitas Lambung Mangkurat.

Luciana, L., Hamzah, A., \& Mardin, M. (2017). Sumber Penghasilan Masyarakat Nelayan. Jurnal Ilmiah Membangun Desa dan Pertanian, 2(1), 20-24.

Natalia, T., Hermanto, H., \& Isamu, K. T. (2019). Uji Sensori, Fisik dan Kimia Kerupuk Ikan Dengan Penambahan Konsentrasi Daging Ikan Gabus (Channa striata) YANG BERBEDA. J. Fish Protech, 2(2), 157164.

Pangerapan, M., Laoh, O. Esry. H., \& Tangkere, E. G. (2018). Analisis Pendapatan Dan Konsumsi Masyarakat Pesisir Pantai (Studi Kasus: Di Dusun Rarumis Desa Karor Kecamatan Lembean Timur). Jurnal AgriSosioekonomi, 14(1), 73-80. https://doi.org/10.35791/agrsosek.14.1.201 8.18960

Purnamayati, L., Dewi, E. N., Sumardianto, S., Rianingsih, L., \& Anggo, A. D. (2019). Kualitas Kerupuk Kulit Ikan Nila Selama Penyimpanan. Jurnal Ilmu Pangan dan Hasil Pertanian, 2(2), 162-172. https://doi.org/10.26877/jiphp.v2i2.3216

Tumbel, N., \& Manurung, S. (2017). Pengaruh Suhu Dan Waktu Penggorengan Terhadap Mutu Keripik Nanas Menggunakan Penggoreng Vakum. Jurnal Penelitian Teknologi Industri, 9(1), 9-22. https://doi.org/10.33749/jpti.v9i1.3204

Zulisyanto, D., Riyadi, P. H., \& Amalia, U. (2016). The Effect of Long Steaming on the Quality of Physical and Chemical Crackers Dumbo Catfish (Clarias gariepinus). $J$. Peng. \& Biotek. Hasil Pi., 5(4), 26-33. 